\title{
The Effect of Intercropping System of Corn (Zea mays, L.) and Peanut (Arachis hypogaea, L.) on Yield Production in Ungaran
}

\author{
DOI: $10.18196 /$ pt.2017.068.88-95
}

\author{
Dharend Lingga Wibisana*, Gunawan Budiyanto, Titiek Widyastuti \\ Department of Agrotechnology, Faculty of Agriculture, Universitas Muhammadiyah Yogyakarta, \\ Jl. Lingkar Selatan, Kasihan, Bantul, Yogyakarta 55183, Indonesia Telp. 0274387656 , \\ *Corresponding author, email: dharendwibi.dl@gmail.com
}

\begin{abstract}
The research was conducted to examine transfer nitrogen from peanut to corn and determine the best planting time of peanut and corn which were cultivated by intercropping system. The research was conducted at dryland of Ungaran Central Java from December 2015 to April 2016. This research was complated using an experimental design with single factor, arranged in completely randomized block design. The treatments were monoculture system of corn (), monoculture system of peanut (K), intercropping system: corn was planted two weeks after peanut (TS 1), intercropping system: peanut was planted two weeks after corn (TS 2), and intercropping system: corn and peanut were planted in the same time (TS 3). Each treatment was replicated 3 times. The results showed that the transfer of nitrogen from peanuts to corn occured when the corn plants were in the stage of maximum vegetative growth. In this research, treatment TS 2 is the best planting time than other treatments as indicated by the yield of 4.02 tonnes corn per hectare. Keywords: Nitrogen, Peanuts, Corn, Monoculture System, Intercropping system
\end{abstract}

\begin{abstract}
ABSTRAK
Penelitian ini dilakukan untuk mengetahui transfer nitrogen kacang tanah pada tanaman jagung dan penentuan waktu tanam jagung dan kacang tanah yang dibudidayakan secara tumpangsari. Penelitian ini telah dilaksanakan di Lahan Kering Kecamatan Ungaran, Jawa Tengah pada bulan Desember 2015 sampai April 2016. Penelitian ini dilaksanakan menggunakan metode eksperimental dengan faktor tunggal yang disusun dalam rancangan acak kelompok lengkap. Perlakuan yang diujikan yaitu Jagung monokultur (), Kacang tanah monokultur (K), Tumpangsari Jagung ditanam 2 minggu setelah tanam kacang tanah (TS 1), Tumpangsari kacang tanah ditanam 2 minggu setalah tanaman jagung (TS 2), dan Tumpangsari Jagung dan Kacang Tanah ditanam bersamaan (TS 3). Setiap perlakuan diulang 3 kali dalam blok. Hasil penelitian ini menunjukkan bahwa transfer nitrogen terjadi pada saat tanaman jagung memasuki pertumbuhan vegetatif maksimum. Perlakuan TS 2 merupakan waktu tanam terbaik dari perlakuan lainnya yang ditunjukkan dengan hasil 4,02 ton jagung per hektar.

Kata kunci: Nitrogen, Kacang tanah, Jagung, Sistem monokultur, Sistem tumpangsari
\end{abstract}

\section{INTRODUCTION}

In Indonesia, corn is one of food sources which has important role for human and animal life. Centre of corn production in Indonesia is located $65 \%$ in Java and others are spread in Lampung, South Sulawesi and Nusa Tenggara. In Java island, corn was cultivated on dry land (77\%) and field (23\%) (Adi and Widyastuti, 2001). Production of corn in 2013 was $18.511 .853 \mathrm{ton} /$ ha then it increased to 20.666.702 ton/ha in 2015 .

The growth of corn until reaching physiologic mature stage needs $120-180 \mathrm{~kg} / \mathrm{ha}$ of nitrogen, while $\mathrm{N}$ which is carried to plant until harvesting and yielding are $129-165 \mathrm{~kg} / \mathrm{ha}$ and 9,5 ton/ha, respectively (Suwardi and Roy Efendi, 2009). To fulfill the needs of nitrogen in corn, cultivation of intercrop which could supply $\mathrm{N}$ (legume) is needed. One of legume plants is peanut which could fix nitrogen to available. Peanut is one of food sources which has high protein and contains niacin, magnesium, vitamin $\mathrm{C}$, mangan, krom and others (Astanto, 2005). Peanut production in 2013 to 2014 decreased from 701.680 ton/ha to 638.896 ton/ha and increased to 657,595 ton/ha in 2015.

Vegetative growth stage of peanut plants begins from germination to first flowering on 26-31 ${ }^{\text {st }}$ days after planting (Trustinah, 1993). On 
vegetative stage, nodule is formed and it fixes Nitrogen. Amin (2007) said that shading the plant from first reproduction stage until before harvesting could cause decreasing of yield about $45 \%$. Therefore, if peanut is intercropped with corn, the growth of peanut could be decreased due to light reduction.

Nitrogen fixation is process where nitrogen from atmosphere is converted to ammonium, ionic form of nitrogen which is available for plant (Budiyanto, 2016). Nitrogen fixation on legume which is planted with non-legume could provide Nitrogen source for non-legume. Reeves (1990) said that transfer of Nitrogen was visible and important in the condition of low Nitrogen availability. Fujita et. al. (1992) said that 24,9\% of nitrogen fixed by Cowpea (Vigna unguiculata L.) was transferred to corn and $10,4 \%$ of nitrogen was transferred from soybean to corn. The number of nitrogen fixation through leguminose was $80-140 \mathrm{~kg} /$ ha per year (Rao, 1797). Generally, nitrogen is taken in the form of ammonium $\left(\mathrm{NH}_{4}^{+}\right)$and nitrate $\left(\mathrm{NO}_{3}{ }^{-}\right)$, but nitrate which is taken soon will be reduced become ammonium through enzym containing molybdenum (Hary, 2008).

The cultivation of corn with peanut as intercrop is called intercropping system. Intercropping system is one of cultivating systems where there are two or more different plants which are planted in the same or different time with regular spacing on an area (Sarman, 2001). Buhaira (2007) said that peanut cultivation between two rows of corn on $100 \mathrm{~cm}$ space yielded 2,93 ton/ ha dry pod. The intercropping of peanut and corn could increase the efficiency of fertilizer and land use under appropriate planting space and time. Sarman and Ardiyaningsih (2000) cit. Buhaira (2007) said that double row of corn with $140 \mathrm{~cm}$ plant spacing between double rows $\mathrm{x} 40$ $\mathrm{cm}$ significantly affected yield of corn, leaf area of soybean and dry weight of corn plant. While during the period of growth until postharvest, corn plants could be more competitive or aggressive than soybean with single row plant spacing $(100 \mathrm{~cm} \times 40 \mathrm{~cm})$.

The aim of this research was to understand the effect of transfer of nitrogen from peanut to corn and determine appropriate planting time interval between peanut and corn by intercropping system.

\section{MATERIALS AND METHODS}

The research was conducted at dryland Ungaran, Semarang and research laboratory of Faculty of Agriculture, Universitas Muhammadiyah Yogyakarta. This research was conducted using an experimental design with single factor, arranged in completely randomized block design. The treatments were :

$\mathrm{J}=$ monoculture system of corn

$\mathrm{K}=$ monoculture system of peanut

TS 1 = intercropping system, corn was planted two weeks after peanut

TS 2 = intercropping system, peanut was planted two weeks after corn

TS 3 = intercropping system, corn and peanut were planted in the same time

Each treatment was replicated 3 times. The observation was carried out on vegetative growth, generative growth and growth analysis.

The data were analyzed using ANOVA (analysis of variance) at a rate of $\alpha 5 \%$. The data of significantly different treatments were further tested by Duncan's multiple range test (Duncan Multiple). 


\section{RESULTS AND DISCUSSIONS}

Vegetative Growth

\section{Plant Height}

Measuring plant height purposed to determine the vegetative growth process of the plant. The results showed that all treatments have same effect on corn and peanut. The average plant height of corn and peanuts are presented in Table 1.

Table 1. Plant Height of Corn and Peanut Plants

\begin{tabular}{ccc}
\hline \multirow{2}{*}{ Treatments } & \multicolumn{2}{c}{ Plant Height $(\mathrm{cm})$} \\
\cline { 2 - 3 } & Corn 7 weeks old & Peanuts 5 weeks old \\
\hline J & 121.83 & - \\
K & - & 26.00 \\
TS 1 & 131.40 & 29.93 \\
TS 2 & 145.93 & 28.80 \\
TS 3 & 116.53 & 23.53 \\
\hline
\end{tabular}

Note: The numbers in the table indicate no significant difference based on the analysis of variance at $5 \%$.

$\mathrm{J} \quad$ : Monoculture system of corn

$\mathrm{K} \quad$ : Monoculture system of corn

TS 1 : Intercropping system, corn was planted two weeks after peanut

TS 2 : Intercropping system, peanut was planted two weeks after corn

TS 3 : Intercropping system, corn and peanut were planted in the same time

Table 1 showed that all treatments have same effect because when the corn plants were 7 weeks old (49 day after planting (DAP)) or in the stage of forming male flowers in which they needed high Nitrogen, the peanut plants in the treatment TS1 were 9 weeks old (63 DAP) or in the

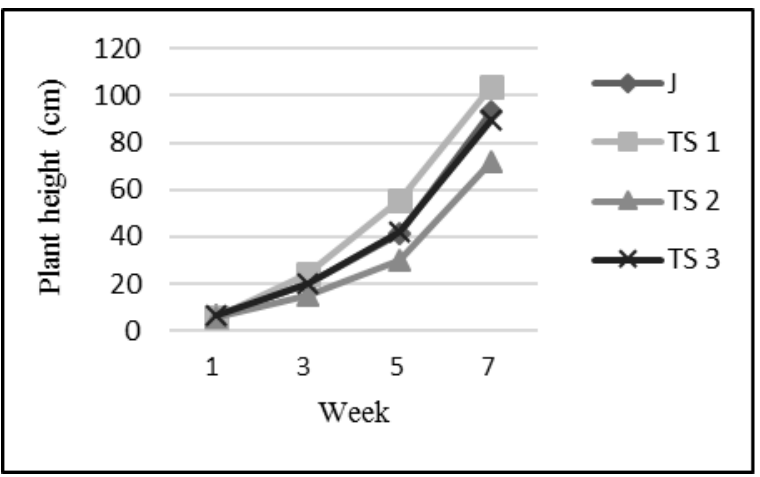

(a)

Figure 1. Plant height of corn (a) forming of filled-seed phase in which they didn't not require high nitrogen. In the treatment TS2, the peanut plants were 5 weeks old (35 DAP) or in the forming of gynophore phase requiring low Nitrogen. While on treatment TS3, the peanut plants were 7 weeks old (49 DAP) or in the forming filled-pods phase that did not require nitrogen in high amounts. Therefore, the nitrogen element produced by the peanut plants can be used for the growth of corn plants.

In peanut crops, the average of plant height on 5 weeks after planting in showed that all treatments have same effect (Table 1). The peanut plants in the treatment TS1, TS2 and TS3 on 5 weeks after planting were shaded by corn that resulted in disruption of the sunlight absorption during photosynthesis and it led to the high growth of peanut plants, while the peanut plants in the treatment $\mathrm{K}$ were likely to get full absorption of sunlight resulted in slower growth of peanut plants because peanut plants were included to the plants requiring partial sunlight absorption. The plant height of corn and peanuts on the $1-7^{\text {th }}$ week were presented in Figure 1.

\section{Number of Leaves}

The result showed that all treatments have

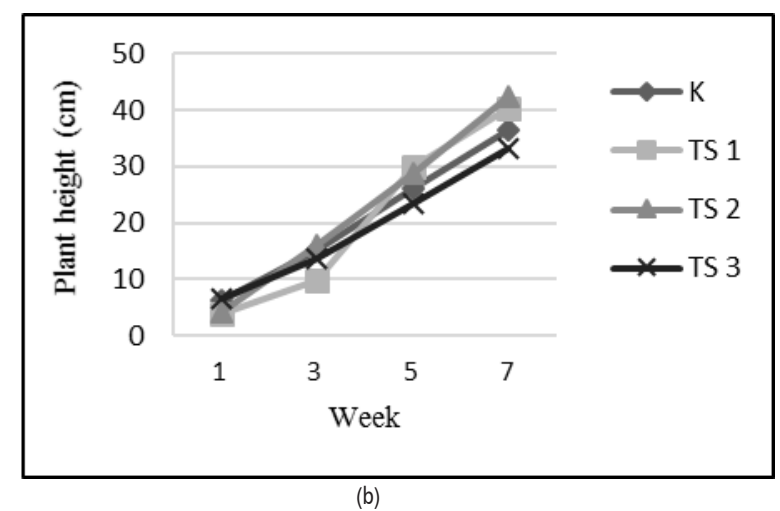

(a), and Plant height of peanut (b)

K: Monoculture system of peanut

TS 2: Intercropping system, peanut was planted two weeks after corn 
same effect on number of leaves. The average of the number of leaves of corn and peanut plants were presented in Table 2 .

Table 2. Number of Leaves of Corn and Peanut Plants

\begin{tabular}{ccc}
\hline \multirow{2}{*}{ Treatments } & \multicolumn{2}{c}{ Number of Leaves (Sheet) } \\
\cline { 2 - 3 } & Corn 7 weeks old & Peanuts 5 weeks old \\
\hline J & 16,00 & - \\
K & - & 34,06 \\
TS 1 & 16,06 & 38,46 \\
TS 2 & 15,73 & 37,33 \\
TS 3 & 15,80 & 31,40 \\
\hline
\end{tabular}

Note: The numbers in the table indicate no significant difference based on the analysis of variance at $5 \%$.

$\mathrm{J} \quad$ : Monoculture system of corn

$\mathrm{K}$ : Monoculture system of peanut

TS 1 : Intercropping system, corn was planted two weeks after peanut

TS 2 : Intercropping system, peanut was planted two weeks after corn

TS 3 : Intercropping system, corn and peanut were planted in the same time

Table 2 showed that the treatments have the same effect. When the corn plants were 7 weeks (49 DAP) entering generative growth phase indicated by the emergence of male flowers and the forming of the last leaf, the element of nitrogen was available from the peanut plants in the treatment TS1, TS2, and TS3. When the corn plants entered the phase of ear and seeds formation, the needs for Nitrogen element in the process of photosynthesis in vegetative growth has decreased (reduced). Actually, the element of nitrogen in plant growth affects leaf area and pre- vents chlorosis, but it does not always determine the number of leaves formed.

Table 2 also showed that all treatments gave the same effect on number of leaves of peanut plants. This is because the peanut plants aged 5 weeks (35 DAP) has reached the phase of gynophore formation, so that the need for nitrogen in the vegetative growth of peanut plants decreased. The growth factor is does not always specify the number of leaves however, the influence of internal factors on peanut plants like the original gene of the peanut plants can determine the number of leaves that are formed in the vegetative growth phase and with the support of climatic conditions (environment) which both will affect the photosynthesis process, so that the leaves formation of peanut plants can still happen. The data on number of leaves of corn and peanut plants on the $1-7^{\text {th }}$ week were presented in Figure 2.

\section{Generative Growth}

\section{Generative Growth of Corn}

Yield component of corn consists of the number of ear, weight of ear with husk, grain dry weight and weight of 100 grains. The data were presented in Table 3. Table 3 showed that

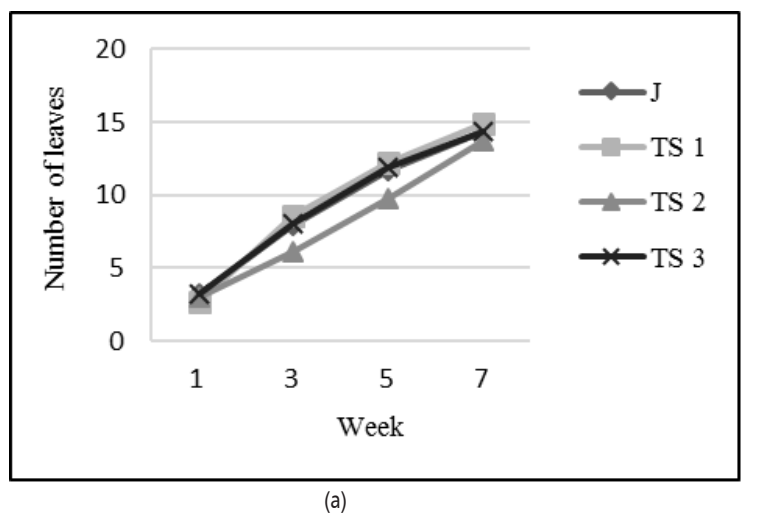

Figure 2. Number of leaves of corn plants

Note:

J: Monoculture system of corn
TS 1: Intercropping system, corn was planted two weeks after peanut
TS 3: Intercropping system, corn and peanut were planted in the same time

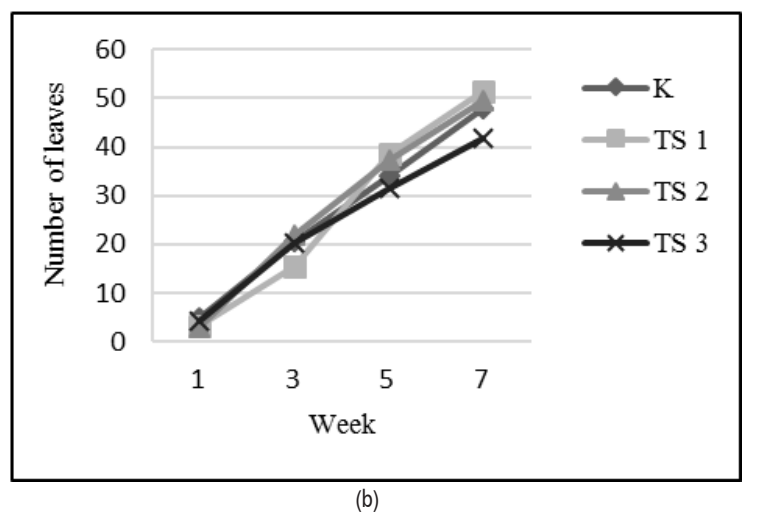

(a), and Number of leaves of peanut plants (b)

K: Monoculture system of peanut TS 2: Intercropping system, peanut was planted two weeks after corn 
all treatments have same effect on the number of ear. It occurred because the peanut plants which supplied $\mathrm{N}$ began to enter generative phase so that Nitrogen production was decreased. It caused the low $\mathrm{N}$ when the second ear appeared. The low availability of $\mathrm{N}$ and fixed $\mathrm{N}$ was also caused by high rain fall.

The result showed that the weight of ear with husk on all treatments were same. It is because the peanut plants supplied $\mathrm{N}$ for ear formation, but deficit of $\mathrm{K}$ during carbohydrates synthesis in the grain could affect the weight of ear with husk. Harvesting which was conducted after rain also affected the humidity of the husk.

Table 3. Number of Ear, Weight of Ear with Husk, Grain Dry Weight and Weight of 100 Grains

\begin{tabular}{ccccc}
\hline Treatments & $\begin{array}{c}\text { Number } \\
\text { of ear }\end{array}$ & $\begin{array}{c}\text { Weight of ear } \\
\text { with husk }(\mathbf{g})\end{array}$ & $\begin{array}{c}\text { Grain dry } \\
\text { weight }(\mathbf{g})\end{array}$ & $\begin{array}{c}\text { Weight of } 100 \\
\text { grains }\end{array}$ \\
\hline J & 1,00 & 291,67 & $627,50 \mathrm{~b}$ & 18,88 \\
TS 1 & 1,00 & 239,97 & $566,67 \mathrm{~b}$ & 21,61 \\
TS 2 & 1,00 & 303,51 & $966,67 \mathrm{a}$ & 27,49 \\
TS 3 & 1,00 & 257,98 & $633,33 \mathrm{~b}$ & 22,51 \\
\hline
\end{tabular}

Note: The numbers in the table indicate no significant difference based on the analysis of variance at $5 \%$.

J : Monoculture system of corn

TS 1 : Intercropping system, corn was planted two weeks after peanut

TS 2 : Intercropping system, peanut was planted two weeks after corn

TS 3 : Intercropping system, corn and peanut were planted in the same time

The result showed that the dry weight of grain of all treatments were significantly different. Table 3 showed that grain dry weight of corn on TS2 was better than the others. It is because when the corn plants entered ear formation phase (7 weeks), they need high $\mathrm{N}$, while the peanut plants on TS1 were 9 weeks which entered pod and grain filling phase, so that $\mathrm{N}$ production was lower than on J. On TS2, the peanut plants were 5 weeks which entered gynophore formation phase, so that $\mathrm{N}$ production on their root was occurring meanwhile their need of $\mathrm{N}$ decreased, so that the $\mathrm{N}$ availability for the corn plants was high during ear and grain filling phase. While on TS3, the peanut plants were 7 weeks which entered pod formation phase. In that phase, their need of $\mathrm{N}$ decreased, but $\mathrm{N}$ production was occurring so it could fulfill the $\mathrm{N}$ need of corn during ear and grain formation.

There was no significant difference on weight of 100 grains among all of treatments. Table 3 showed that intercropping the peanut plants gave the same effect on weight of 100 grains of corn compared to monoculture system. It is because the cell division of ear was occurring. It affected the form and size of the grains, which were also affected by nutrients especially N. Besides, the solid grain of corn was due to complete composition of $\mathrm{K}$ in carbohydrate formed in corn grain.

\section{Generative Growth of Peanut}

Observation was carried out on number of pod, pod dry weight, and weight of 100 grains. The data were presented in Table 4.

Table 4. Number of Pod, Pod Dry Weight, and Weight of 100 Grains of Peanut

\begin{tabular}{cccc}
\hline Treatments & Number of pod & Pod dry weight (g) & $\begin{array}{c}\text { Weight of 100 } \\
\text { grains (g) }\end{array}$ \\
\hline K & 26,13 & $631,67 \mathrm{a}$ & 54,50 \\
TS 1 & 28,73 & $466,67 \mathrm{~b}$ & 53,63 \\
TS 2 & 25,66 & $383,33 \mathrm{~b}$ & 52,71 \\
TS 3 & 24,80 & $385,00 \mathrm{~b}$ & 50,51 \\
\hline
\end{tabular}

Note: The numbers in the table indicate no significant difference based on the analysis of variance at $5 \%$.

$\mathrm{K} \quad$ : Monoculture system of peanut

TS 1 : Intercropping system, corn was planted two weeks after peanut

TS 2 : Intercropping system, peanut was planted two weeks after corn

TS 3 : Intercropping system, corn and peanut were planted in the same time

There was no significant difference on number of pod (Table 4). When the corn plants were 7 weeks after planting in which they needed $\mathrm{N}$ for ear forming, on TS1 the peanut plants were 9 weeks after planting (max filling of grain) so there was no $\mathrm{N}$ absorption competition. On TS2 the peanut plants were 5 weeks after planting (gynophore forming) so there was no $\mathrm{N}$ absorption competition, but the peanut plants supplied 
$\mathrm{N}$ for ear forming. While on TS3, the peanut plants were 7 weeks after planting (max filling of grain) in which the need of $\mathrm{N}$ decreased. Trustinah (1993) mentioned that reproductive phase of peanut was divided into 8 stadia, that were flowering (27-37 DAT), gynophore forming (32-36 DAT), pod forming (40-45 DAT), max pod filling (44-52 DAT), grain forming (52-57 DAT), max grain filling (60-68 DAT), maturing of grain (6875 DAT) and mature harvesting (80-100 DAT).

There was significant difference on pod dry weight between monoculture and intercropping system (Table 4). Monoculture system produced the highest pod dry weight while TS1, TS2 and TS3 were the same. It is because monoculture system has the highest population. Beside that size and number of pod forming on $\mathrm{K}$ because of availability of $\mathrm{N}$ from peanut used for peanut without corn.

Table 4 showed that there was no significant difference on 100 grains weight among all treatments because the nutrients especially $\mathrm{N}$ affected pod forming on 6-7 weeks after planting, while pod forming would determine the size of and uniformity of the grain. It means that the competition of $\mathrm{N}$ absorption between peanut and corn would cause the varied size of grain and affect the weight of 100 grains.

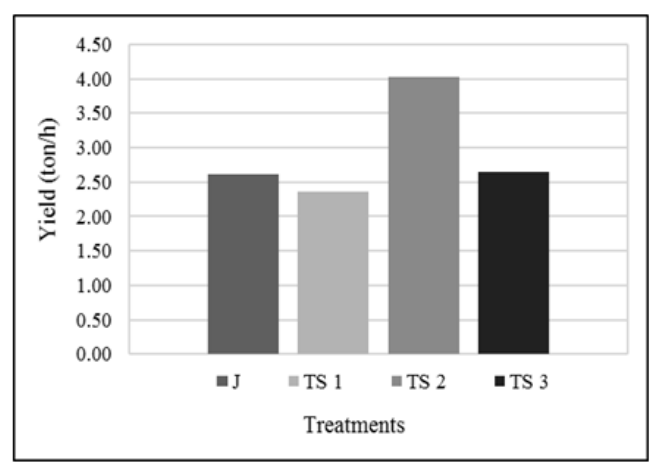

(a)

Figure 3. Number of leaves of corn plants (a), and Number of leaves of peanut plants (b)

Note: J: Monoculture system of corn

TS 1: Intercropping system, corn was planted two weeks after peanut TS 3: Intercropping system, corn and peanut were planted in the same time and Peanut
Yield and Land Equivalent Ratio (LER) of Corn

The analysis results on yield of corn and peanut which was converted to ton/ha showed that there was significant difference among all treatments. While the results of analysis on LER showed that there was significant difference between monoculture and intercropping system. The average of yield and LER were presented in Table 5.

Table 5. Yield and Land Equivalent Ratio of Corn and Peanut

\begin{tabular}{cccc}
\hline Treatments & $\begin{array}{c}\text { Yield of Corn } \\
\text { (ton/ha) }\end{array}$ & $\begin{array}{c}\text { Yield of Peanut } \\
\text { (ton/ha) }\end{array}$ & LER \\
\hline J & $2,62 \mathrm{~b}$ & - & - \\
K & - & $2,58 \mathrm{a}$ & - \\
TS 1 & $2,35 \mathrm{~b}$ & $1,91 \mathrm{~b}$ & $1,76 \mathrm{~b}$ \\
TS 2 & $4,02 \mathrm{a}$ & $1,58 \mathrm{~b}$ & $2,29 \mathrm{a}$ \\
TS 3 & $2,64 \mathrm{~b}$ & $1,59 \mathrm{~b}$ & $1,63 \mathrm{~b}$ \\
\hline
\end{tabular}

Note: The numbers in the table indicate no significant difference based on the analysis of variance at $5 \%$.

$\mathrm{J}$ : Monoculture system of corn

$\mathrm{K}$ : Monoculture system of peanut

TS 1 : Intercropping system, corn was planted two weeks after peanut

TS 2 : Intercropping system, peanut was planted two weeks after corn

TS 3 : Intercropping system, corn and peanut were planted in the same time

Table 5 showed that yield of TS2 was higher than monoculture. It showed that intercropping system of corn and peanut was better than monoculture system. Yield of TS1 and TS3 was same with monoculture system. But the average

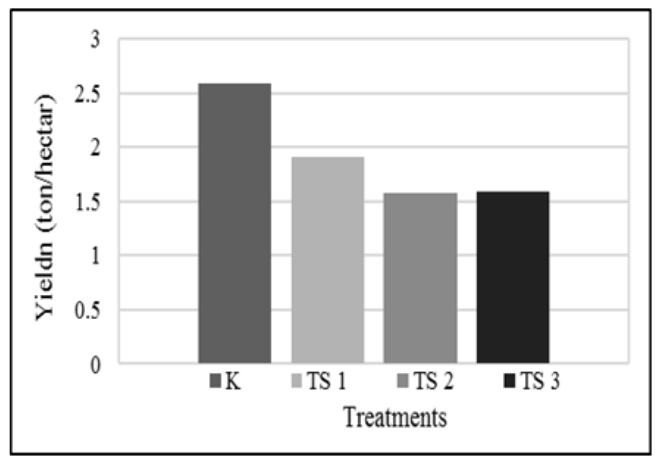

(b) 
of corn yield on TS2 was not in accordance with certification standard. Balai Penelitian Tanaman Serealia (2010) determined that corn Bisi 18 have average yield about 9,1 ton/ha while in this research it only reached 4,03 ton/ha of dry shelled corn (Figure 3a). It occurred because the ear growth on TS2 was bigger than other which resulted in higher number of grain. Besides, when entering ear forming phase (7 weeks) which needs high $\mathrm{N}$, the peanut plants on TS1 was 9 weeks after planting where $\mathrm{N}$ fixation decreased leading to lower availability of $\mathrm{N}$ compared to $\mathrm{J}$. On TS2, the peanut plants were entering gynophore forming phase ( 5 weeks) in which $\mathrm{N}$ fixation was occurring. Therefore, the $\mathrm{N}$ availability ear formation was increased. While on T3, the peanut plants were entering pod forming phase (7 weeks) where the need of $\mathrm{N}$ decreased but the $\mathrm{N}$ fixation was occurring resulted in the provision of $\mathrm{N}$ to develop ear and grain.

The dry pod of peanut for monoculture system was higher than other because the growth process was without disturbance of climate during flowering process so that the pod forming was optimal (Table 5). Besides, it was affected by bigger size and higher number of pod. The max yield in this research was 2,5 ton/ha (Figure 3b), which is in accordance with Suhartina (2005) who reported that peanut cv. Gajah reached 1,82,0 ton/ha of dry pod.

LER of TS2 was higher than other treatments (Table 5). While, TS1 and TS3 have the similar of LER value. If the value of LER is more than 1 , it means intercropping system was success because it produced the higher yield than monoculture did. The high value of LER means that productivity of land was also high. High productivity of land showed that the land use was maximal. In the same area, intercropping system produced higher yield than monoculture system.

\section{CONCLUSION}

Transfer of nitrogen from peanut to corn occurred when the corn plants were in the stage of maximum vegetative growth. In this research, intercropping system of peanut which was cultivated 2 weeks after corn was is the best planting system as indicated by the yield of 4.02 ton corn per hectare. Farmers who will cultivate practicing intercropping system of corn and peanut are recommended to plant peanut 2 weeks after corn. The next research needs to consider the better planting time of peanut and corn, the parameter used and the time when nitrogen production decreases.

\section{ACKNOWLEDGEMENTS}

Thanks to PT. Indofood Sukses Makmur, Tbk that has provided research grants through Indofood Riset Nugraha 2015/2016 program. We also greatly appreciate to the two anonymous reviewers who gave us valuable and fruitful comments.

\section{REFERENCES}

Adi Sarwanto and Widyastuti. 2001. Increasing Corn Production. Penebar Swadaya.Jakarta.86 p.

Afandhie Rosmarkam and Nasih W.Y. 2002. Study of Soil Fertility. Kanisius. Yogyakarta. 224 p.

Amin Zuhri. 2007. Optimalisasi Hasil Tanaman Kacang Tanah Dan Jagung Dalam Tumpangsari Melalui Pengaturan Baris Tanam Dan Perompesan Daun Jagung. Embryo 4(2): 156-163.

Astanto Kasno. 2005. Profil dan Perkembangan Teknik Produksi Kacang Tanah di Indonesia. Makalah Seminar. Seminar Rutin Puslitbang Tanaman Pangan Bogor.

Badan Pusat Statistik. 2015. Survey of Agriculture : Corn and Peanut Productionin Indonesia on year 2013 - 2015. Accessed on 1 july 2015. www.bps.go.id.

Balai Penelitian Tanaman Serealia. 2010. DescriptionSuperior Variety of Corn. Center of Research and Development Food Crop in Research Center of Sereal Crops. Maros. 118 p.

Budiyanto, G. 2016. Pengendalian Pencucian Senyawa Nitrat Guna Meningkatkan Produktivitas Lahan Marginal Pantai KuIon Progo DIY. PLANTA TROPIKA: Jurnal Agrosains (Journal of Agro Science) 4(1): 46-57. doi:http://dx.doi.org/10.18196/ pt.2016.056.46-57.

Buhaira. 2007. Respons Kacang Tanah dan Jagung Terhadap Beberapa Pengaturan Jarak Tanam Jagung pada Sistem Tanam Tumpangsari. Jurnal Agronomi 11(1): 41-46. 
Fujita K., Ofusu-Budu, K.G., and Ogata, S. 1992. Biological Nitrogen Fixation in Mixed Legume-Cereal Cropping Systems. Plant and Soil 141 (1-2): 155-175.

Gardner, F. P., R. B. Dearce dan R. L. Michell. 1991. Physiologhy of Crops (Translator Herawati Susilo). UI Press. Jakarta. 428 p.

Hary Sarsini. 2008. Pengaruh Pengolahan Tanah Dan Pupuk N Serta Pupuk Kandang Terhadap Serapan Ca, S Dan Kualitas Hasil Kacang Tanah (Arachis hypogaea L.) pada alfisols. Skipsi. Fakultas Pertanian. Universitas Sebelas Maret Surakarta. Surakarta. 110 p.

Mul Mulyani Sutejo. 2002. Fertilizers and Fertilitation Way. Rineka Cipta. Jakarta. 177 p.

Reeves, M. 1992. The Role of VAM Fungi in Nitrogen Dynamics in Corn-Bean Intercrops. Plant and Soil 144 (1): 85-92.

Sarman S. 2001. Kajian Tentang Kompetisi Tanaman dalam Sistem Tumpangsari di Lahan Kering. Jurnal Agronomi 5 (1): 89-96

Suhartina. 2005. Description Superior Sariety of Peanuts and Tubers. Reasearch Center of Peanuts and Tubers Crop. Malang. $153 \mathrm{p}$.

Suwardi and Roy Efendi. 2009. Efisiensi Penggunaan Pupuk N Pada Jagung Komposit Menggunakan Bagan Warna Daun. Balai Penelitian Tanaman Serealia. Prosiding Seminar Nasional Serealia.

Trustinah. 1993. Peanut Biology. Monograf Balittan Malang No 12. Malang. 9-12 p. 